\title{
Development of a New Refrigerant Mixture (RM-1) to improve the performance of Heat Pump System for Heating and Cooling of the Living Space
}

\author{
Song, Heon* Ro, Jeong-Geun**
}

*School of Architectural Engineering, Hongik University(archilieu@hotmail.com), **School of Mechanical Engineering, Chungbuk National University(jeonguen@chungbuk.ac.kr)

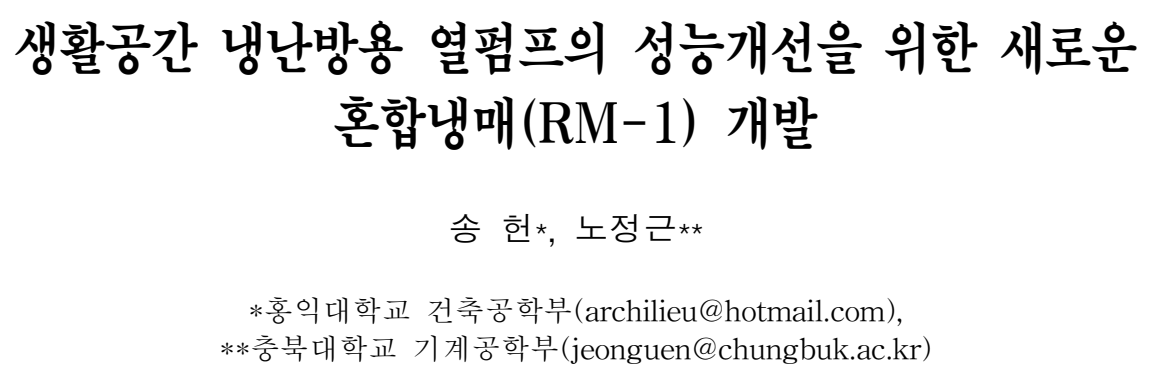

\begin{abstract}
생활공간 냉난방용 열펌프의 성능향상을 위해 R22의 대체 냉매로서 새로운 혼합냉매R22/R23/R152a(RM-1)을 개 발하고 U. S. A.의 NIST사의 REFPROP program을 이용해 이 혼합냉매의 P-h diagram을 구성하여 실용화에 이용할 수 있도록 하였다. 본 연구는 실험을 통해 R22와 RM- 1 의 열폄프 성능효과를 분석하였다. 입·출구 물의 온도와 제 2 의 전열매체로서 물의 질량유량, 압축기의 소요 에너지 그리고 열펌프의 기타 열적 특성을 다양한 조건하에서 측정하 였다. 이 실험 데이터를 통해 공기-물 열펌프 시스템에서의 RM-1과 R22의 성능계수(COP)를 비교하였다. 이를 통해, 혼합냉매 RM-1을 사용하는 열폄프 시스템은 외기온 $-17^{\circ} \mathrm{C}$ 에서도 2.2 의 성능계수로 작동하는 결과를 본 연구에서 보여주었다.
\end{abstract}

투고일자 : 2011년 8월 5일, 심사일자 : 2011년 8월 8일, 게재확정일자 : 2011년 10월 14일

교신저자 : 송헌(archilieu@hotmail.com) 


\section{Nomenclature}

\begin{tabular}{|c|c|}
\hline$m_{r}$ & $\begin{array}{l}\text { mass flow rate of } \\
\text { refrigerant }(\mathrm{kg} / \mathrm{hr})\end{array}$ \\
\hline $\mathrm{m}_{\mathrm{w}}$ & $\begin{array}{l}: \text { mass flow rate of water } \\
(\mathrm{kg} / \mathrm{hr})\end{array}$ \\
\hline$m_{\text {air }}$ & $\begin{array}{l}\text { : mass flow rate of air } \\
(\mathrm{kg} / \mathrm{hr})\end{array}$ \\
\hline $\mathrm{h}_{\mathrm{RM}-1,}, \mathrm{~h}_{\mathrm{R} 22}$ & : enthalpy $(\mathrm{kcal} / \mathrm{kg})$ \\
\hline $\mathrm{Cp}_{\mathrm{w}}$ & $\begin{array}{l}\text { : specific heat of water } \\
\left(\mathrm{kcal} / \mathrm{kg} .{ }^{\circ} \mathrm{C}\right)\end{array}$ \\
\hline $\mathrm{Cp}_{\text {air }}$ & $\begin{array}{l}\text { specific heat of air } \\
\left(\mathrm{kcal} / \mathrm{kg} .{ }^{\circ} \mathrm{C}\right)\end{array}$ \\
\hline $\mathrm{T}_{\mathrm{w}, \text { out }}$ & $\begin{array}{l}\text { : outlet water temperature of } \\
\text { condenser }\left({ }^{\circ} \mathrm{C}\right)\end{array}$ \\
\hline $\mathrm{T}_{\mathrm{w}, \text { in }}$ & $\begin{array}{l}: \text { inlet water temperature } \\
\text { of condenser }\left({ }^{\circ} \mathrm{C}\right)\end{array}$ \\
\hline $\mathrm{T}_{\text {air,out }}$ & $\begin{array}{l}\text { outlet air temperature of } \\
\text { evaporator }\left({ }^{\circ} \mathrm{C}\right)\end{array}$ \\
\hline $\mathrm{T}_{\text {air,in }}$ & $\begin{array}{l}\text { : inlet air temperature of } \\
\text { evaporator }\left({ }^{\circ} \mathrm{C}\right)\end{array}$ \\
\hline $\mathrm{T}_{\mathrm{amb}}$ & $:$ ambient air temperature $\left({ }^{\circ} \mathrm{C}\right)$ \\
\hline$\dot{\mathrm{Q}}_{\text {Ele }}$ & $\begin{array}{l}\text { : power consumption of } \\
\text { compressor }(\mathrm{kW})\end{array}$ \\
\hline$\dot{\mathrm{Q}}_{\mathrm{EAV}}$ & $\begin{array}{l}\text { : absorption heat of } \\
\text { evaporator }(\mathrm{kW})\end{array}$ \\
\hline$\dot{\mathrm{Q}}_{\text {Loss }}$ & $\begin{array}{l}\text { : heat loss of the system } \\
(\mathrm{kW})\end{array}$ \\
\hline$\dot{\mathrm{Q}}_{\text {gain }}$ & $\begin{array}{l}: \text { heat gain of the } \\
\text { condenser }(\mathrm{kW})\end{array}$ \\
\hline $\mathrm{T}_{\mathrm{w}, \mathrm{outR2} 2}$ & $\begin{array}{l}\text { outlet temperature of } \\
\text { water heated by the } \\
\text { condenser using } \mathrm{R}_{22} \text { as } \\
\text { refrigerant }\left({ }^{\circ} \mathrm{C}\right)\end{array}$ \\
\hline $\mathrm{T}_{\mathrm{w}, \text { outRM-1 }}$ & $\begin{array}{l}\text { outlet temperature of } \\
\text { water heated by the } \\
\text { condenser using } \mathrm{RM}-1 \\
\text { as refrigerant }\left({ }^{\circ} \mathrm{C}\right)\end{array}$ \\
\hline
\end{tabular}

\section{Introduction}

The ozone depletion and the global warming problems have been accelerated and seriously concerned with CFCs and HCFCs.

Nowadays the development of alternative refrigerants has become an urgent research topic all over the world.

According to this situation, ASHRAE (1993) reports (Montreal Protocol) that the consumption of HCFC should have been reduced down to $65 \%$ of the 1989 level by $2004,35 \%$ by $2010,10 \%$ by $2015,0.5 \%$ by the 2020 and completely phased out by the year of 2030 .

In literatures, several researchers have proceeded to achieve the new alternative refrigerants, Sung-Tack Ro et al. (1995) have tested the $R_{134 a}, R_{152 a}$ and $R_{22} / R_{142 b}$ mixture(50/50 by mass) as the alternatives to $R_{12}$, and $R_{134 a}$ to $R_{22}$.

He et al. (2009) have undertaken to examine the characteristics of $\mathrm{R}_{22}+\mathrm{DMF}$ (dimethylformamide), $\mathrm{R}_{134 a}+\mathrm{DMF}$, and $\mathrm{R}_{32}+\mathrm{DMF}$ as working fluids, respectively, for a single stage intermitted absorption refrigerator.

Sami and Tulei(1995) have reported that the blend used in CFIA(Combined Cycle Fully Integrated Air/Air Heat Pump) is composed of HFC-23/HCFC-22/HFC-152a and it has an ozone depletion potential (ODP) of $50 \%$ less than HCFC-22.

In this study, not only to meet the global warming potential (GWP), but also to decrease the ozone depletion potential(ODP), a new refrigerant mixture, $R_{22} / \mathrm{R}_{23} / \mathrm{R}_{152 \mathrm{a}}(\mathrm{RM}-1)$ was developed and the thermodynamics properties of ternary mixture were analyzed by the software REFOROP proposed by NIST of U. S. A.

And in order to analyze the coefficient of performance (COP) of the air-to-water heat 


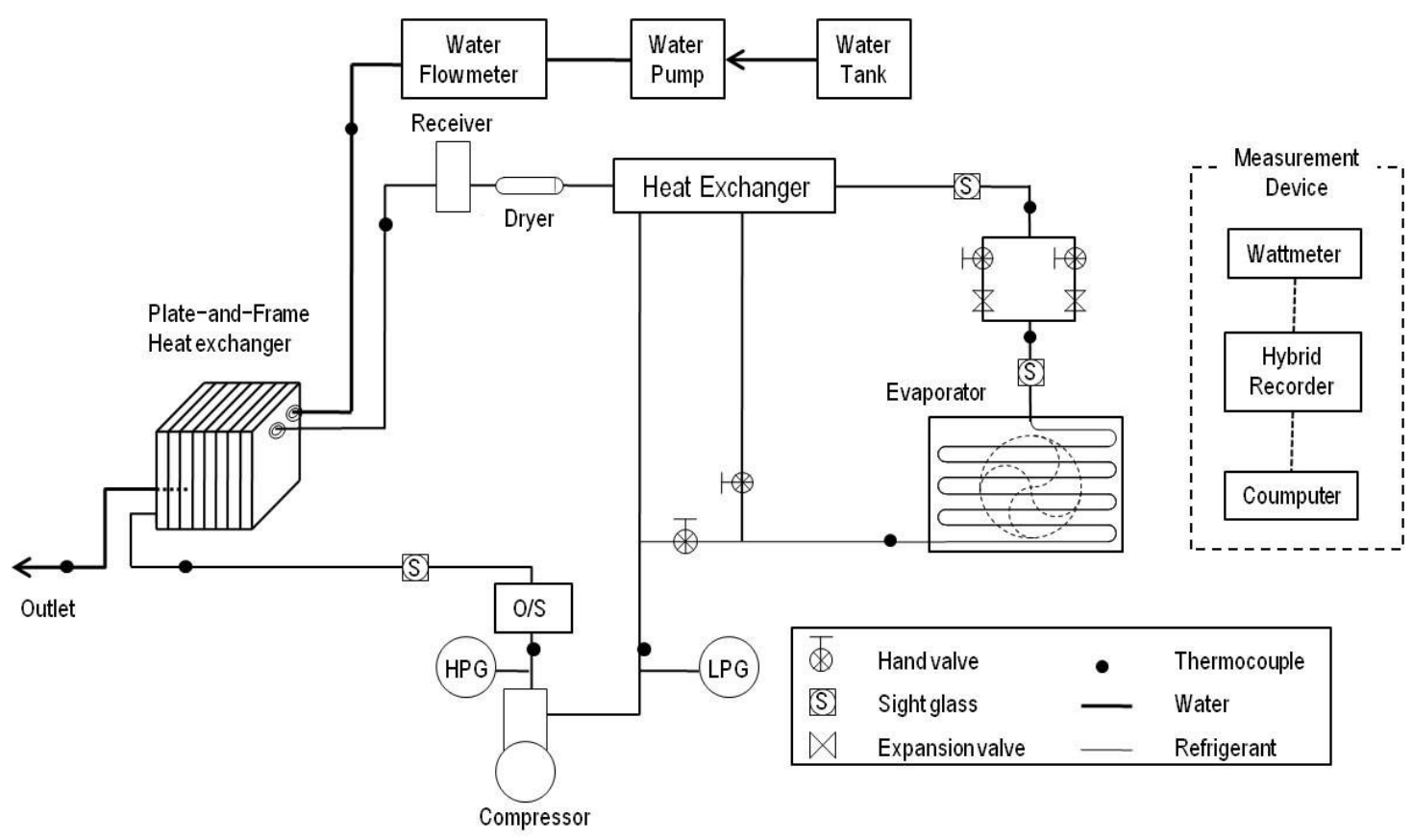

Fig 1. The air-to-water heat pump circuit and experimental apparatus in this study.

pump using the new RM-1, the experiment was performed to obtain the data effected to the heat pump, and the COP was calculated by using the experimental data.

\section{Composition of heat pump circuit and the thermal characteristics}

\subsection{Composition of the air-to-water heat pump circuit}

The composition of the air-to-water heat pump circuit is shown in Fig.1. It consisted of compressor, evaporator and condenser for heating the water, heat exchanger for super cooling extension, expansion valves and some kinds of connecting pipes.

\subsection{The heat pump cycle on the basic pressure-enthalpy $(\mathrm{P}-\mathrm{h})$ diagram of a refrigerant.}

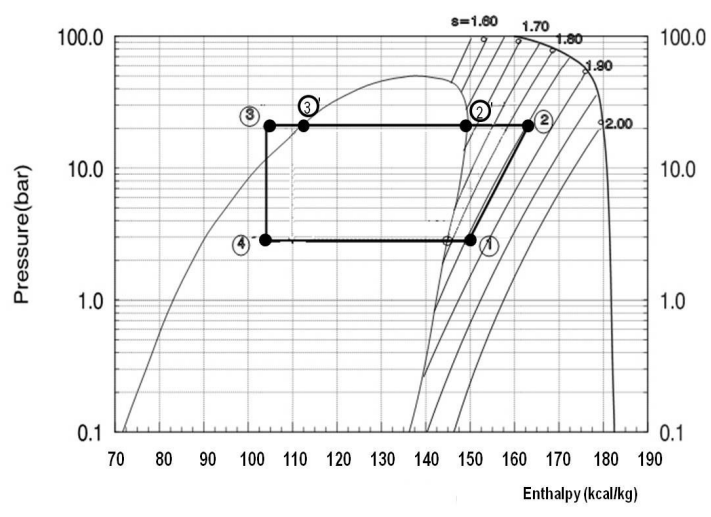

Figure 2. The heat pump cycle on the basic $\mathrm{P}-\mathrm{h}$ diagram of a refrigerant.

The solid line (1)-(2)-(2)'-(3)'-(3)-(4) in Fig.2 is the air-to-water heat pump cycle composed on the basic pressure-enthalpy $(\mathrm{p}-\mathrm{h})$ diagram.

As shown in Fig.2. solid line (1)-(2) is the compression process of the compressor, (2)-

(3) condensing process of condenser for the 
water heating, (3)-(4) expansion process and (4)-(1) evaporating process of evaporator, and also (3) ${ }^{\prime}$-(3) is super cooling portion and (2) ${ }^{\prime}-$ (2) super heating portion.

And then the super heating and cooling portion could be considered as the important factor to improve the coefficient of performance (COP) of the heat pump system.

\subsection{Thermal energy balance of heat pump}

The thermal energy balance of the heat pump cycle on the $\mathrm{P}-\mathrm{h}$ diagram shown in Fig. 2. could be analyzed as follows;

- Thermal energy balance

$\dot{\mathrm{Q}}_{\text {gain }}=\dot{\mathrm{Q}}_{\mathrm{EAV}}+\dot{\mathrm{Q}}_{\text {Ele }}-\dot{\mathrm{Q}}_{\mathrm{Loss}}$

- Power consumption of compressor

$\dot{\mathrm{Q}}_{\text {Ele }}=\mathrm{P}(\mathrm{kW}) \times 860(\mathrm{kcal} / \mathrm{kWh})=\mathrm{m}_{\mathrm{r}}\left(\mathrm{h}_{2}-\right.$

$\mathrm{h}_{1}$ )

- Heat gain of condenser

$\dot{\mathrm{Q}}_{\text {gain }}=\mathrm{m}_{\mathrm{r}}\left(\mathrm{h}_{2}-\mathrm{h}_{3}\right)$

$$
=\mathrm{m}_{\mathrm{w}} C \mathrm{p}_{\mathrm{w}}\left(\mathrm{T}_{\mathrm{w}, \text { out }}-\mathrm{T}_{\mathrm{w}, \text { in }}\right)
$$

- Absorption heat of evaporator from the air heat source

$\dot{\mathrm{Q}}_{\mathrm{EAV}}=\mathrm{m}_{\mathrm{r}}\left(\mathrm{h}_{1}-\mathrm{h}_{4}\right)=\mathrm{m}_{\text {air }} \mathrm{Cp}_{\text {air }}\left(\mathrm{T}_{\text {air,out }}\right.$ $\left.\mathrm{T}_{\text {air,in }}\right)$

- COP : Coefficient of performance

$\mathrm{COP}=\frac{\dot{Q}_{\text {gain }}}{\dot{Q}_{\mathrm{Ee}}+\dot{Q}_{\text {Loss }}}$

\section{Thermal Characteristics of RM-1 and $R_{22}$}

The thermal characteristics of the refrigerant mixture (RM-1) developed in this study and the refrigerant $\mathrm{R}_{22}$ are as follows. Fig.3 is the heat pump cycle on $\mathrm{P}-\mathrm{h}$ diagram of the refrigerant $\mathrm{R}_{22}$ and Fig.4 is the heat pump cycle on the $\mathrm{P}-\mathrm{h}$ diagram of the refrigerant mixture, $\mathrm{RM}-1$.

\subsection{Performance characteristics of the heat pump with the refrigerant $R_{22}$}

The actual cycle of the heat pump system differs from the ideal cycle due to the heat losses, pipe friction and irreversible process, but in general to simplify the analysis of the energy balance, the ideal cycle theory could be used for the analysis of the thermal characteristics of the heat pump system.

According to the experiment, the heat pump cycle using $\mathrm{R}_{22}$ (Fig.3) on the $\mathrm{P}-\mathrm{h}$ chart of $\mathrm{R}_{22}$ could consist of constant discharge pressure process of $20 \mathrm{bar}$, constant suction pressure process of $3 \mathrm{bar}$, the constant enthalpy process of $110 \mathrm{kcal} / \mathrm{kg}$ and compression process of the enthalpy from $148 \mathrm{kcal} / \mathrm{kg}$ to $161 \mathrm{kcal} / \mathrm{kg}$.

In the heat pump cycle as shown in Fig.3, the energy used by the compressor was $\Delta$ $\mathrm{h}_{\text {comp. }}=12 \mathrm{kcal} / \mathrm{kg}$, the thermal energy absorbed from the evaporator, $\Delta \mathrm{h}_{\text {eva. }}=38 \mathrm{kcal} / \mathrm{kg}$ and the thermal energy discharged from condenser, $\Delta \mathrm{h}_{\text {cond. }}=51 \mathrm{kcal} / \mathrm{kg}$, and then the heat $(\Delta$ $\mathrm{h}_{\text {cond. }}=51 \mathrm{kcal} / \mathrm{kg}$ ) rejected from the condenser could be the available energy for the space heating.

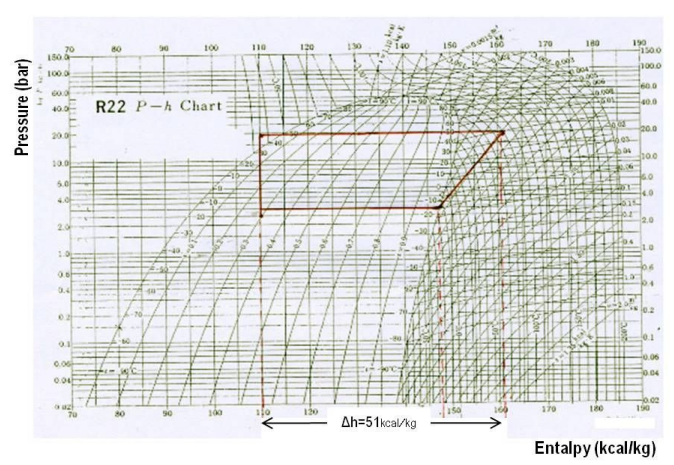

Figure 3. Heat pump cycle on the $p-h$ diagram of $R_{22}$

한국태양에너지학회 논문집 Vol. 31, No. 5, 2011 


\subsection{Performance characteristics of the heat pump with the refrigerant mixture RM-1}

The $\mathrm{P}-\mathrm{h}$ diagram of the refrigerant mixture RM-1 developed in this study is shown in Fig.4.

The saturated liquid-gas line and temperature variation of $\mathrm{RM}-1$ were analyzed by the software REFPROP (NIST of U.S.A.) program and these results could be presented on the $\mathrm{P}-\mathrm{h}$ diagram of RM-1.

In general, during the vaporization process, the refrigerant exists as a liquid-gas mixture phase on the saturated liquid-gas line, but the proportion of the liquid and gas phases in the $\mathrm{P}-\mathrm{h}$ diagram of $\mathrm{RM}-1$ could not be analyzed by the REFPROP program.

As shown in Fig.4, the air-to-water heat pump cycle could be presented on the $\mathrm{P}-\mathrm{h}$ diagram of RM-1 through the four processes of the air-to-water heat pump using the RM-1.

And then, for the presentation of the RM-1 thermal properties of the heat pump cycle, it is convenient to describe the change of pressure, enthalpy, temperature and energy consumption per unit mass during four processes of one cycle of heat pump.

Here, the heat pump cycle on the $\mathrm{P}-\mathrm{h}$ diagram of RM-1 was performed with the constant discharge pressure of $20 \mathrm{bar}$, the constant suction pressure of $3 \mathrm{bar}$, the constant enthalpy of $54 \mathrm{kcal} / \mathrm{kg}$ and compression process of the enthalpy variation from 100 $\mathrm{kcal} / \mathrm{kg}$ at $-13^{\circ} \mathrm{C}$ to $115 \mathrm{kcal} / \mathrm{kg}$ at $90^{\circ} \mathrm{C}$.

Then, the thermal energy of $46 \mathrm{kcal} / \mathrm{kg}$ $\left(\Delta \mathrm{h}_{\text {Eva }}\right)$ absorbed by the evaporator and the energy of $61 \mathrm{kcal} / \mathrm{kg}\left(\Delta \mathrm{h}_{\text {cond }}\right)$ discharged from the condenser could be used as the available energy for the space cooling and heating.

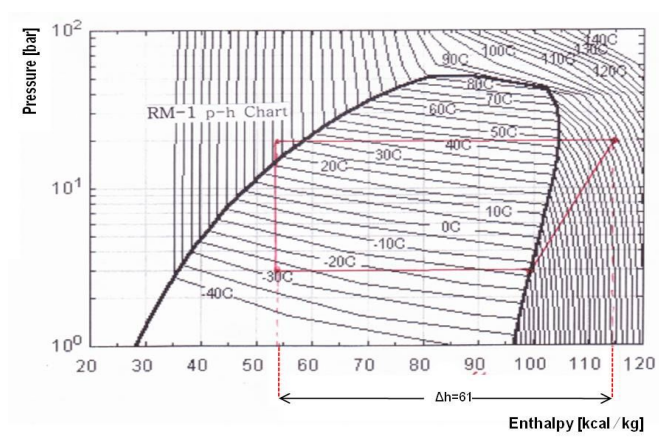

Figure 4. Heat pump cycle on the $\mathrm{p}-\mathrm{h}$ diagram of $\mathrm{RM}-1$.

\subsection{Comparison of performance characteristics between $\mathrm{R}_{22}$ and $\mathrm{RM}-1$}

In order to compare the useful energy gained from the heat pump system using $\mathrm{R}_{22}$ and that from the system using RM-1, the available energy that could be gained from the ideal cycle of the heat pump on the $\mathrm{P}-\mathrm{h}$ diagram of $\mathrm{R}_{22}$ and $\mathrm{RM}-1$ was obtained theoretically under the general operation conditions of the heat pump cycle, the conditions being the compressor suction and discharge temperature of $-15^{\circ} \mathrm{C}$ and $90^{\circ} \mathrm{C}$ and the suction and discharge pressure of 3 bar and 20 bar, respectively.

The useful energy obtained from the $\mathrm{P}-\mathrm{h}$ diagram of $\mathrm{R}_{22}$ and $\mathrm{RM}-1$ was $51 \mathrm{kcal} / \mathrm{kg}$ and $61 \mathrm{kcal} / \mathrm{kg}$, respectively.

This result shows that the useful energy obtained from RM-1 was $10 \mathrm{kcal} / \mathrm{kg}$ larger than that from $\mathrm{R}_{22}$.

And then, in case of water heating with the useful energy difference (enthalpy difference) of $10 \mathrm{kcal} / \mathrm{kg}$ between RM-1 and $R_{22}$, the temperature increase of water could be derived as follows;

Enthalpy in the water heated by the condenser using $\mathrm{R}_{22}$ as a refrigerant could be calculated as follows; 
$\mathrm{h}_{\mathrm{R} 22}=\mathrm{m}_{\mathrm{w}} \mathrm{cp} \mathrm{p}_{\mathrm{w}}\left(\mathrm{T}_{\text {woutR22 }}-\mathrm{T}_{\text {win }}\right)$

And the enthalpy in the water heated by the condenser using RM-1 as a refrigerant mixture could be calculated as follows;

$\mathrm{h}_{\mathrm{RM}-1}=\mathrm{m}_{\mathrm{w}} \mathrm{cp} \mathrm{p}_{\mathrm{w}}\left(\mathrm{T}_{\text {woutRM-1 }}-\mathrm{T}_{\text {win }}\right) \cdots \cdots(7)$

Equation (7) minus equation (6);

$\Delta \mathrm{h}=\mathrm{h}_{\mathrm{RM}-1}-\mathrm{h}_{\mathrm{R} 22}$

$=\mathrm{m}_{\mathrm{w}} \mathrm{cp} \mathrm{p}_{\mathrm{w}}\left(\mathrm{T}_{\text {woutRM }-1}-\mathrm{T}_{\text {winR22 }}\right)$

$\Delta \mathrm{T}=\left(\mathrm{T}_{\text {woutRM-1 }}-\mathrm{T}_{\text {winR22 }}\right)=\Delta \mathrm{h} / \mathrm{m}_{\mathrm{w}} \mathrm{cp}_{\mathrm{w}}$

Substituting the numerical values

$\left(\Delta \mathrm{h}=10 \mathrm{kcal} / \mathrm{kg}, \mathrm{Cp}=1 \mathrm{kcal} / \mathrm{kg}^{\circ} \mathrm{C}\right)$ into Eq. (8) ;

$\Delta \mathrm{T}=10^{\circ} \mathrm{C} / \mathrm{m}_{\mathrm{w}}$

As shown in the Eq.(8) and Eq.(9), the temperature increase of water heated by the enthalpy difference of $10 \mathrm{kcal} / \mathrm{kg}$ was in inverse proportion to water mass flow rate, and in proportion to the enthalpy difference.

\section{Experimental work}

In order to verify that the thermal characteristics analyzed theoretically on the $\mathrm{p}$-h diagram of RM-1 (Fig.4) are far better than the usual refrigerant $\mathrm{R}_{22}$, the experiments were carried out as follows;

\subsection{Experimental equipment}

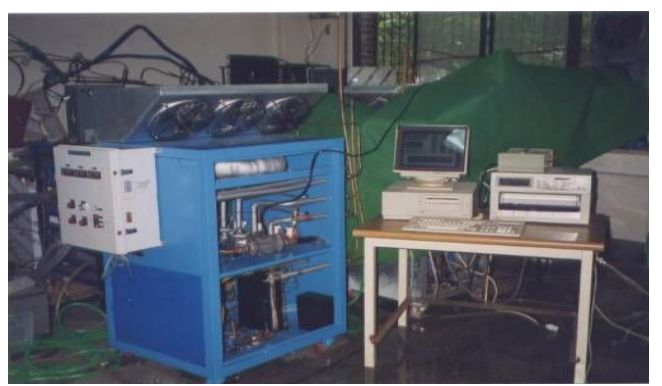

Figure 5. Experimental equipment composed of the PC-based automatic data acquisition unit and the heat pump system (2.2 kW).
As shown in Fig.1, the air-to-water heat pump circuit was composed of a compressor of $2.2 \mathrm{~kW}$, a condenser of flat-plate frame heat exchanger and an evaporator of fin and tube heat exchanger and nine measuring points of T-type thermocouples on the circuit were connected to a PC-based automatic data acquisition unit.

As the photo shows in Fig.5, the heat pump circuit and the experimental equipment (Fig.1) were manufactured.

The data acquisition unit monitored the inlet and outlet temperature of the water and refrigerant as working fluids circulating in the heat pump system and ambient air temperature, and then the water flow rate was measured with the water flow meter, and the electrical power consumption of the system was monitored with the energy analyzer (VIP watt meter, model; VIP system 3 Energy Analyzer, ELCONTROL Co., Italy).

The unit also scanned all channels at 30-minute intervals, and before the start of the test, the system was preconditioned so as to make it start under the same condition.

\subsection{Experimental method}

In order to evaluate the thermal effectiveness of RM- 1 on the performance of the air-to-water heat pump system in the winter season in Korea (below $-10^{\circ} \mathrm{C}$ of the ambient air temperature), the variables, monitoring scope and scanning interval were combined as Table 1.

These experiments were carried out from January to April, 2009 in Cheongju, Korea.

Several experimental measurements were made by Table 1, and the collected data were used to analyze the useful thermal energy, power consumption including some 
kinds of losses of the system and the COP of the system with the ambient air temperature variation.

Table 1. Combination of variables and monitoring scope $P_{h}=$ High pressure of refrigerant circuit $P_{L}=$ Low pressure of refrigerant circuit

\begin{tabular}{|c|c|c|c|}
\hline \multicolumn{2}{|c|}{ Variable } & $\begin{array}{c}\text { Monitoring } \\
\text { scope }\end{array}$ & $\begin{array}{c}\text { Scanning } \\
\text { interval } \\
\text { (min.) }\end{array}$ \\
\hline \multirow{5}{*}{ RM-1 } & $\mathrm{T}_{\text {amb. }}\left({ }^{\circ} \mathrm{C}\right)$ & $-17 \sim 7$ & 30 \\
\cline { 2 - 4 } & $\mathrm{T}_{\mathrm{w}}\left({ }^{\circ} \mathrm{C}\right)$ & $7 \sim 50$ & $"$ \\
\cline { 2 - 4 } & $\mathrm{m}_{\mathrm{w}}(\mathrm{l} / \mathrm{h})$ & $100 \sim 300$ & $"$ \\
\cline { 2 - 4 } & $\dot{\mathrm{Q}}_{\mathrm{Ele} .}(\mathrm{kW})$ & $1.47 \sim 2.2$ & $"$ \\
\cline { 2 - 4 } & $\begin{array}{c}\mathrm{P}_{\mathrm{h}} \& \mathrm{P}_{\mathrm{L}} \\
\left(\mathrm{kg} / \mathrm{cm}^{2}\right)\end{array}$ & $3 \& 20$ & $"$ \\
\hline \multirow{5}{*}{$\mathrm{R}_{22}$} & $\mathrm{~T}_{\text {amb. }}\left({ }^{\circ} \mathrm{C}\right)$ & $-17 \sim 7$ & $"$ \\
\cline { 2 - 4 } & $\mathrm{T}_{\mathrm{w}}\left({ }^{\circ} \mathrm{C}\right)$ & $7 \sim 50$ & $"$ \\
\cline { 2 - 4 } & $\mathrm{m}_{\mathrm{w}}(\mathrm{l} / \mathrm{h})$ & $100 \sim 300$ & $"$ \\
\cline { 2 - 4 } & $\dot{\mathrm{Q}}_{\mathrm{Ele} .}(\mathrm{kW})$ & $1.47 \sim 2.2$ & $"$ \\
\cline { 2 - 4 } & $\begin{array}{c}\mathrm{P}_{\mathrm{h}} \& \mathrm{P}_{\mathrm{L}} \\
\left(\mathrm{kg} / \mathrm{cm}^{2}\right)\end{array}$ & $3 \& 20$ & $"$ \\
\hline
\end{tabular}

\section{Results and Discussion}

In order to verify the relative superiority of the newly developed refrigerant mixture $\mathrm{RM}-1$ to $\mathrm{R}_{22}$, the $\mathrm{P}-\mathrm{h}$ diagram of the RM-1 was composed as shown in Fig.4, and the heat gain and power consumption of the system using RM-1 were estimated by the enthalpy difference method on the $\mathrm{P}-\mathrm{h}$ diagram, and then to confirm that the estimated values mentioned above could be available, the temperature variation of the water heated in accordance with the water mass flow rate $\left(\mathrm{m}_{\mathrm{w}}\right)$ was analyzed experimentally, and the heat gain $\left(\dot{Q}_{\text {gain }}\right)$ of the system could be calculated by substituting these experimental data into the Eq. (3) derived at the section 2.3. Also the power consumption $\left(\dot{\mathrm{Q}}_{\mathrm{Ele}}\right)$ of the system was measured with the energy analyzer.

Therefore the COP of the system could be evaluated by substituting the heat gain $\left(\dot{\mathrm{Q}}_{\text {gain }}\right)$ and power consumption $\left(\dot{\mathrm{Q}}_{\text {Ele }}\right)$ into Eq. (5). Finally, it was possible to compare the COP of the system using RM-1 with that of the system using $R_{22}$.

\subsection{Effect of RM-1 on the heated water temperature.}

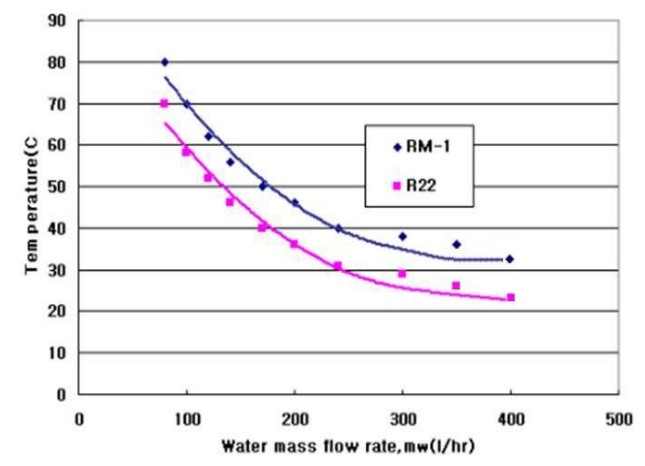

Figure 6. Heated water temperature variation with water mass flow rate of the heat pump system using $\mathrm{RM}-1$ or $\mathrm{R}_{22}$ (water inlet temperature $=15^{\circ} \mathrm{C}$ )

Fig.6 shows the heated water temperature variation with water mass flow rate of the heat pump system using $\mathrm{RM}-1$ or $\mathrm{R}_{22}$.

In general, the outlet temperature of the heated water decreased as a concave curve with the increase in water mass flow rate. In this case the water inlet temperature was $15^{\circ} \mathrm{C}$.

As shown in Fig.6, the temperature of the water heated by the system using $\mathrm{RM}-1$ was about $10^{\circ} \mathrm{C}$ higher than that of the system using $R_{22}$.

\subsection{Effect of RM-1 on the power consumption}

Fig.7 shows the variation of power consumption of the heat pump system using 
RM-1 and $\mathrm{R}_{22}$ in accordance with the ambient air temperature variation.

As shown in Fig.7, the power consumption of the heat pump system using RM-1 increased from 1.8 to $2.6 \mathrm{~kW}$ in accordance with the increase in the ambient air temperature from -5 to $4^{\circ} \mathrm{C}$.

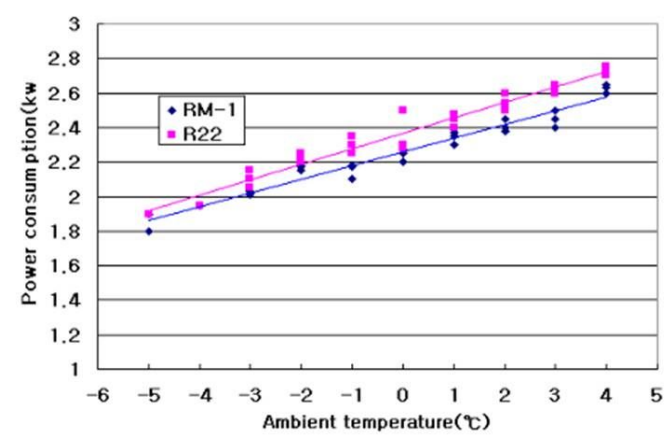

Figure 7. Variation of the power consumption of the heat pump system using $\mathrm{RM}-1$ or $\mathrm{R}_{22}$ with the ambient air temperature

On the other hand, in case of the system using $\mathrm{R}_{22}$, the power consumption increased from 1.9 to $2.79 \mathrm{~kW}$ with the increase of the ambient air temperature from -5 to $4^{\circ} \mathrm{C}$.

Therefore, the heat pump system using RM-1 could save the power of $0.19 \mathrm{~kW}$ (7.4\%) compared with the system using $\mathrm{R}_{22}$.

\subsection{Effect of RM-1 on the COP.}

In order to evaluate the COP of the system, the terms of the heat gain and power consumption including heat losses of the system could be calculated as follows;

First, substituting the inlet and outlet temperature variation and water mass flow rate derived from Fig.6 into Eq.(3), the heat gain could be provided.

Second, the power consumption of the compressor was estimated by the enthalpy difference method derived from Eq.(2), and the power consumption including some kind of losses of the system was able to provide with the experimental data as shown in Fig.6.

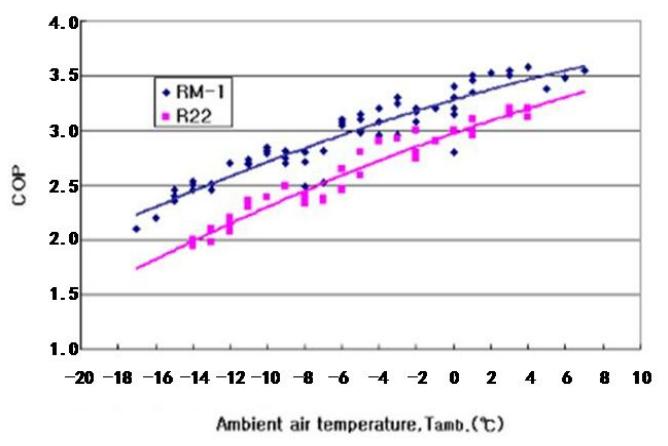

Figure 8. COP variation with the ambient air temperature of the heat pump system using $\mathrm{RM}-1$ or $\mathrm{R}_{22}$ as refrigerant

Fig. 8 is the COP curves in case of RM- 1 and $R_{22}$ derived from the process mentioned above. As shown in Fig.8, COP in case of RM-1 increased from 2.2 to 3.5 with the increase in the ambient air temperature from -17 to $7^{\circ} \mathrm{C}$, whereas that in case of $\mathrm{R}_{22}$ was increased from 2.0 to 3.2 with the increase from -14 to $4^{\circ} \mathrm{C}$. Consequently, the $\mathrm{COP}$ of the system using RM-1 as refrigerant mixture was $0.4 \sim 0.5$ larger than that of the system using $\mathrm{R}_{22}$.

Therefore, the power consumption of the system could be reduced by using $\mathrm{RM}-1$ in the heat pump system instead of using $\mathrm{R}_{22}$. So far, it has been one of the most difficult problems to operate the heat pump with high efficiency at the ambient air temperature below $-10^{\circ} \mathrm{C}$. Now, the problem could be solved by realizing the use of $\mathrm{RM}^{-1}$ as refrigerant mixture for the heat pump system.

As shown in Fig.8, the system using RM-1 
was able to operate with COP of 2.2 even at the ambient air temperature of $-17^{\circ} \mathrm{C}$.

The results showed that the COP of the heat pump system using $\mathrm{RM}-1$ as a working fluid was $0.5 \sim 0.6$ larger than that in case of $R_{22}$ under the ambient temperature of $-17 \sim-14^{\circ} \mathrm{C}$.

\section{Conclusion}

Not only to meet the global warming potential(GWP) but also to decrease the ozone depletion potential(ODP), the new refrigerant mixture $R_{22} / R_{23} / R_{152 a}(R M-1)$ was developed as an alternative to $R_{22}$ in this study, and in order to present the thermal characteristics of $\mathrm{RM}-1$, its $\mathrm{p}^{-\mathrm{h}}$ diagram was composed by the software REFPROP proposed by NIST of U. S. A.

To present the effect of the RM-1 as refrigerant mixture for the heat pump system, the experiments were carried out and the results were summarized as follows;

- The temperature of water heated by the air-to-water heat pump system (2.2 $\mathrm{kW})$ using $\mathrm{RM}-1$ was about $10^{\circ} \mathrm{C}$ higher than that of the system using $\mathrm{R}_{22}$.

- The power consumption of the system using RM-1 increased from 1.8 to 2.6 $\mathrm{kW}$, whereas that of the system using $\mathrm{R}_{22}$ from 1.9 to $2.79 \mathrm{~kW}$ with the increase in the ambient air temperature from -5 to $4^{\circ} \mathrm{C}$.

- The COP of the system using RM-1 as refrigerant mixture were $0.4 \sim 0.5$ larger than that of the system using $R_{22}$. Therefore, the power consumption of 7.4\% could be saved by using $\mathrm{RM}-1$ instead of $\mathrm{R}_{22}$.
- In order to solve the difficult problem with the operation of the heat pump system at the ambient air temperature below $-10^{\circ} \mathrm{C}$, the refrigerant mixture RM -1 has been developed and used for the system.

\section{Bibliography}

1. Chapon C., Delandre M., Air Conditioning by Heat Pump on the Water Loop, ASHRAE Trans, Vol. 97, No. 1, 1991

2. Damasceno G.S., Douanski P.A., Rooke S., Refrigerant Charge Effects on Heat Pump Performance, ASHRAE Transaction Research, pp. 304-310.

3. Ko G.S., Kim J.Y., Park Y.C., Solar Assisted and Air Heat Source using Multi Source Heat Pump System, The Korea Society of Power System Engineering Winter Conference, 2005, pp.67-72

4. He L.J., Tang L.M., Chen G.M., Performance Prediction of Refrigerant-DMF Solutions in Single-Stage solar powered Absorption Refrigeration System at Low Generating Temperatures, International Solar Energy Society, Vol. 83, No. 11, 2009.

5. Kim M.S., Chang S. D., Ro S.T., Experimental study on the performance of Heat Pump Using Refrigerant Mixture R22/R142b, Korean Journal of Air-conditioning and Refrigeration Engineering, Vol. 4, No. 1, 1992.

6. Maake W., Eckert H. J., Cauchepin J.L., Manuel Technique du Froid, LE POHL MANN-deuxième édition PYC, 1993, pp.260-327.

7. Mulroy W., Karffeld M., Experimental Evaluation of Two Refrigerant Mixtures 
in Breadboard Air Conditioner. Proc. of Int. Inst. Refrigeration Predue Conf. on CFCs, Commissions B1, B2, E1 \& E2, 1988, pp.27-34.

8. Park J.K. and Song H.K. (Korea), Development of Simulation Model for Ondol Heating System with Heat Pump and Latent Heat Storage Unit. Thesis for a Doctorate, 2002.

9. Rapin. P.J., Jacquard P., Installations Frigorifiques, Tome1, PYC edition, 1996, pp.198-246.

10. Sami S.M., Tulei P.J., A New Design for An Air-Source Heat Pump Using a Ternary Mixture for Cold Climates. Heat Recovery System \& CHP, Vol. 5, No. 6, 1995, pp.521-529.

11. Xu Guoying, Zhang Xiaosong, Deng Shiming, A Simulation Study on the Operating Performance of a Solar-Air Source Heat Pump Water Heater, Applied Thermal Engineering, Vol. 26, 2006, pp.1257-1265.

12. Chang T.S., Shin J.Y., Ro S.T.(Korea), Performance and Evaluation of a Refrigeration System with Alternative Refrigerants to R12 and R22, Journal of Air-Conditioning and Refrigeration, Vol. 3, 1995, pp.12-20. 